\title{
A SIMPLE WAY TO REDUCE HEAT STRESS IN LAYING HENS AS JUDGED BY EGG LAYING, BODY WEIGHT GAIN AND BIOCHEMICAL PARAMETERS
}

\author{
K. ŞAHINN* and O. KüÇÜK \\ Department of Animal Nutrition, Veterinary Faculty of Furat University, 23119 Elazı̆̆ \\ Turkey
}

(Received June 20, 2001; accepted September 5, 2001)

\begin{abstract}
This study was designed to test the effects of feed withdrawal and darkening on the performance, triiodothyronine (T3), thyroxine (T4), thyroid-stimulating hormone (TSH), adrenocorticotropic hormone (ACTH), and some blood serum metabolite and mineral concentrations of laying hens reared at high ambient temperatures ranging from 25 to $35^{\circ} \mathrm{C}$. Ninety, 16-week-old hens (Ross Brown) were divided into 3 groups, 30 hens each. The first group was used as control. Hens in the second group (feed withdrawal) were subjected to feed removal from 14:00 to 18:00, and hens in the third group (darkening) were subjected to light restriction from 14:00 to 18:00 using black curtains. Liveweight, feed intake, and egg production were higher $(\mathrm{P}<0.01)$ in the feed withdrawal and darkening groups, particularly in the darkening group, than in the control. Water intake was higher in the control group compared with the feed withdrawal and darkening groups $(\mathrm{P}<$ 0.01). T3, T4, and TSH concentrations in the serum were higher $(\mathrm{P}<0.01)$, whereas ACTH serum concentration was lower $(\mathrm{P}<0.01)$ in the feed withdrawal and darkening groups compared with the control. The haematocrit was higher in the feed withdrawal and darkening groups compared with the control $(\mathrm{P}<0.01)$. Darkening and feed withdrawal treatments increased serum glucose, urea- $\mathrm{N}$, uric acid, albumin, triglyceride, cholesterol, $\mathrm{Ca}, \mathrm{P}, \mathrm{Na}$, and $\mathrm{K}$ concentrations, also the activities of amylase and alkaline phosphatase, but did not influence the activities of serum glutamic-oxaloacetic transaminase (SGOT) and serum glutamic pyruvic transaminase (SGPT). The present study found that feed withdrawal and darkening, particularly darkening, at high temperatures during the summer months offer a good management practice to reduce heat stress related depression in feed intake and egg production in laying hens.
\end{abstract}

Key words: Laying hen, heat stress, darkening, feed withdrawal, performance

High environmental temperature leads to physiological changes in laying hens such as increased water and decreased feed intake, egg quality (Emery et al., 1984; Sauveur and Picard, 1987) and thyroid activity (Evans and Ingram,

*Corresponding author; Dr. Kazım Şahin, Veteriner Kontrol ve Araştırma Enstitüsü, 23119 Elazığ, Turkey; E-mail: ksahin@firat.edu.tr; Fax: +90 (424) 233-8720 
1977; Bowen and Washburn, 1985). Plasma $T_{3}$ and $T_{4}$, important growth promoters in animals, are reduced during heat stress (Heninger et al., 1960; Bowen et al., 1984; Hilman et al., 1985; McNabb and King, 1993), and appear to be positively related to feed intake (Klandorf and Harvey, 1985). During heat stress, plasma corticosterone concentration increases (Edens and Siegel, 1975), whereas glucose, total protein, uric acid, albumin, triglyceride, and cholesterol concentrations decrease (Meluzzi et al., 1992; Chiericato et al., 1994).

In Turkey and in many countries of the world, particularly those in the tropical areas, high environmental temperature, negatively affecting performance of chickens, is of major concern to chicken producers. In such countries and in most part of Turkey during the summer months, ambient temperature at 14:00 to 18:00 ranges from 30 to $40{ }^{\circ} \mathrm{C}$. Several methods are available to alleviate the negative effects of high environmental temperature on the performance of poultry. Since it is expensive to cool animal buildings, such methods are focused mostly on dietary and housing manipulations. Although several studies have been conducted to alleviate the effects of heat stress on chicken performance (Feenster, 1985; Musharaf and Jansen, 1990; Kutlu and Forbes, 1995; McKee et al., 1997), there have been no studies reported restricting the period of time at which hens receive artificial and natural light (daylight) during the day. Therefore, the aim of this work was to determine the effects of darkening and feed withdrawal on feed intake, liveweight, egg production, T3, T4, TSH, ACTH, and some metabolite and mineral concentrations in the serum of laying hens during the summer months when the temperature of hen houses rises up to $35^{\circ} \mathrm{C}$.

\section{Materials and methods}

\section{Hens and diet}

Ninety, 16-week-old healthy Ross Brown hens were obtained from a commercial company (Koytur, Elazig, Turkey). The hens were randomly assigned to three caging units, 30 hens each, according to their liveweight. Each caging unit also contained six subcages, five hens per subcage $(30 \times 45 \times 35 \mathrm{~cm})$. The cages in the hen house were lit for $17 \mathrm{~h}$ per day. During the experiment, ambient temperatures outside were obtained from a local weather forecast station, and the temperature of the hen house was measured daily at 08:00, 14:00, 18:00, 22:00, and 02:00. Ambient relative humidity inside the hen house ranged from 50 to $60 \%$, whereas ambient relative humidity outside was reported as 30 to $55 \%$ by the local weather forecast station. The mean values of daily temperature changes in the hen house ranged from 25 to $35^{\circ} \mathrm{C}$, whereas ambient temperature outside was reported as 30 to $40{ }^{\circ} \mathrm{C}$ by the local weather forecast station. The experiment, 16 weeks in duration, was conducted between June 3 and September 23 after an adaptation period of a week for diet. The experiment was in accor- 
dance with animal welfare and ethics, and was conducted under protocols approved by the Veterinary Control and Research Institute of Elazig, Turkey.

The hens received a typical layer diet containing $11.29 \mathrm{MJ} / \mathrm{kg}$ and $15 \%$ crude protein $/ \mathrm{kg}$ (Table 1 ) to meet or slightly exceed the nutrient requirements recommended by the National Research Council (1994). Hens consumed water and the diet ad libitum throughout the study. At weekly intervals, feed intake was determined on group basis, whereas at biweekly intervals body weights were recorded on individual basis. Daily egg production was also measured.

Table 1

Ingredients and chemical composition of the diet fed to laying hens

\begin{tabular}{lr}
\hline \multicolumn{1}{c}{ Ingredients } & $\%$ \\
\hline Corn & 56.62 \\
Soybean meal & 10.68 \\
Wheat bran & 20.00 \\
Fish meal & 4.46 \\
Limestone & 7.26 \\
Vitamin premix $^{*}$ & 0.25 \\
Mineral premix $^{* *}$ & 0.10 \\
Sodium chloride $_{\text {Sodium bentonite }}^{* * *}$ & 0.25 \\
Oxinyl-Dry $^{*}$ & 0.10 \\
\hline
\end{tabular}

Dry matter, \% 89.78

\begin{tabular}{|c|c|}
\hline Chemical analysis (DM basis) & $\%$ \\
\hline $\mathrm{ME}, \mathrm{kcal} / \mathrm{kg}^{* * * *}$ & 2700 \\
\hline Crude protein, \% & 15.00 \\
\hline Ash, $\%$ & 11.31 \\
\hline Crude fibre, $\%$ & 4.28 \\
\hline Ether extract, \% & 3.51 \\
\hline Calcium, \% & 3.00 \\
\hline Phosphorus, \% & 0.51 \\
\hline \multicolumn{2}{|c|}{ 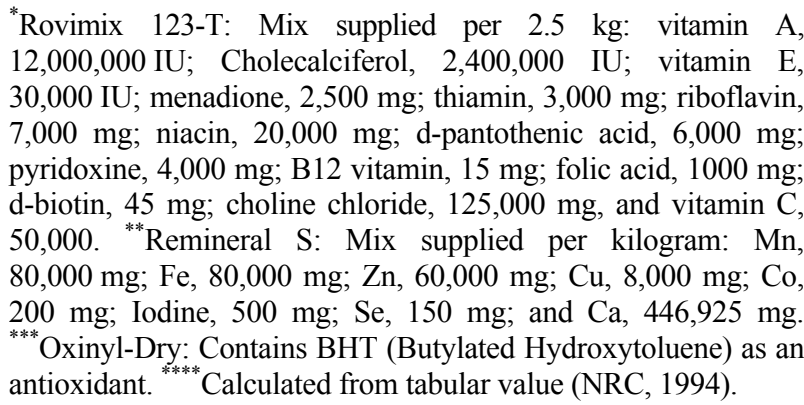 } \\
\hline
\end{tabular}




\section{Experimental design}

All three groups received the same diet (Table 1). The first group of hens was used as control. Hens in the second group were used as a feed withdrawal group and were subjected to complete feed removal from 14:00 to 18:00. Hens in the third group were used as a darkening group and were subjected to light restriction for $4 \mathrm{~h}$ between 14:00 to 18:00 using black curtains. The time period for darkening was chosen based on our previous observation that the temperature measured in the hen house reached maximum values during these hours of the day. The total hours of light per day in each treatment was the same $(17 \mathrm{~h})$ as hens in the darkening group received light at night as well when the other groups went to sleep or rest. The lights were switched on right after sunset and were switched off upon completion of $17 \mathrm{~h}$ for the total period of time of light.

\section{Sample collection and laboratory analyses}

Chemical analysis of the diet, except crude fibre, was run using international procedures of AOAC (1990) and crude fibre was determined as described by Crampton and Maynard (1938) (Table 1). At the end of 16 weeks, 10 hens randomly chosen from each treatment were bled from the jugular vein and $10 \mathrm{ml}$ blood was collected into tubes. Blood samples were centrifuged at $3000 \times \mathrm{g}$ for $10 \mathrm{~min}$ and $4 \mathrm{ml}$ of serum was collected and stored at $-20^{\circ} \mathrm{C}$ for later analysis. For haematocrit measurement, blood from the vena brachialis under the wing was taken into heparinized capillary tubes and centrifuged for $7 \mathrm{~min}$. Serum samples were thawed at room temperature, and T3, T4, TSH, and ACTH concentrations were determined using commercially available radioimmunoassay kits (Renden et al., 1994) (Liaison ${ }^{\circledR}$ T3, T4 and TSH, Byk-Sangtec Diagnostica, Dietzenbach-Germany; Immulite 2000 ACTH, L2 KAC2, DPC, LA). Intra- and interassay coefficients of variation were 6.12 and $9.55 \%$ for T3, 15.33 and $5.86 \%$ for T4, 12.93 and 7.60 for TSH and 10.65 and 7.95 for ACTH, respectively. Serum glucose, total protein, urea-N, uric acid, albumin, triglyceride, cholesterol, $\mathrm{Ca}, \mathrm{P}, \mathrm{Na}$, and $\mathrm{K}$ concentrations, and amylase, alkaline phosphatase, SGOT, and SGPT activities were measured using a biochemical analyser (Technicon RAXT, New York, USA).

\section{Statistical analyses}

All data were analyzed using the General Linear Models of SAS (SAS Institute, 1985). Differences among the means were separated using Duncan's multiple range test. Differences at the level of $5 \%$ were considered statistically significant. 


\section{Results}

The effects of feed withdrawal and darkening during heat stress on performance are shown in Table 2. Feed withdrawal and darkening increased feed intake $(\mathrm{P}<0.01)$, liveweight $(\mathrm{P}<0.05)$, and egg production $(\mathrm{P}<0.01)$. These parameters were higher in the darkening group than in the feed withdrawal group. Water intake was higher in the control group compared to that of feed withdrawal and darkening groups $(\mathrm{P}<0.01)$.

Table 2

The effects of feed withdrawal and darkening on the performance of laying hens reared under heat stress

\begin{tabular}{|c|c|c|c|}
\hline Item & Control $^{+}$ & Feed withdrawal & Darkening \\
\hline Feed intake, $\mathrm{g} / \mathrm{d}$ & $112 \pm 9.8^{\mathrm{a}}$ & $118 \pm 9.7^{\mathrm{b}}$ & $124 \pm 10.0^{\mathrm{c}}$ \\
\hline Feed intake, $\%$ increase $^{*}$ & - & 5.35 & 10.71 \\
\hline Water intake, $\mathrm{ml} / \mathrm{d}$ & $405 \pm 3.1^{\mathrm{a}}$ & $375 \pm 2.4^{\mathrm{b}}$ & $359 \pm 2.4^{\mathrm{c}}$ \\
\hline Water intake, $\%$ decrease ${ }^{*}$ & - & 7.16 & 11.35 \\
\hline Liveweight, $g$ & $1890 \pm 18.2^{\mathrm{a}}$ & $1920 \pm 20.2^{b}$ & $1961 \pm 17.1^{\mathrm{c}}$ \\
\hline Liveweight, \% increase ${ }^{*}$ & - & 1.58 & 3.74 \\
\hline Egg production, $\%$ & $56.11 \pm 4.1^{\mathrm{a}}$ & $62.43 \pm 5.1^{\mathrm{b}}$ & $69.79 \pm 4.2^{\mathrm{c}}$ \\
\hline Egg production, $\%$ increase ${ }^{*}$ & - & 11.26 & 24.38 \\
\hline
\end{tabular}

${ }^{\mathrm{a}, \mathrm{b}, \mathrm{c}}$ Means in the same row with different superscripts differ $(\mathrm{P}<0.05)$; ${ }^{+}$recommended values; *compared with control

Serum T3, T4, and TSH concentrations were also higher $(\mathrm{P}<0.05)$ in the feed withdrawal and darkening groups than in the control (Table 3). However, ACTH concentration in the serum was lower $(\mathrm{P}<0.05)$ in the darkening and feed withdrawal groups compared with control.

\section{Table 3}

The effects of feed withdrawal and darkening on serum concentrations of $\mathrm{T}_{3}, \mathrm{~T}_{4}, \mathrm{TSH}$ and ACTH in laying hens reared under heat stress $(n=10)$

\begin{tabular}{lcccc}
\hline \multicolumn{1}{c}{ Item, ng/ml } & Control & Feed withdrawal & Darkening & Reference values \\
\hline $\mathrm{T}_{4}$ & $4.41 \pm 0.25^{\mathrm{a}}$ & $4.86 \pm 0.27^{\mathrm{b}}$ & $5.07 \pm 0.28^{\mathrm{c}}$ & $4.2-20.6^{1,2,3}$ \\
$\mathrm{~T}_{3}$ & $0.94 \pm 0.13^{\mathrm{a}}$ & $1.08 \pm 0.15^{\mathrm{b}}$ & $1.36 \pm 0.17^{\mathrm{c}}$ & $0.3-2.6^{1,2,3}$ \\
$\mathrm{TSH}$ & $0.10 \pm 0.01^{\mathrm{a}}$ & $0.15 \pm 0.01^{\mathrm{b}}$ & $0.23 \pm 0.02^{\mathrm{c}}$ & $0.15-1.8^{3,4}$ \\
$\mathrm{ACTH}$ & $20.33 \pm 1.02^{\mathrm{a}}$ & $18.67 \pm 1.18^{\mathrm{b}}$ & $16.66 \pm 1.22^{\mathrm{c}}$ & $11-26^{1,2,3}$ \\
\hline
\end{tabular}

a,b,c Means in the same row with different superscripts differ $(\mathrm{P}<0.05) ;{ }^{1}$ Renden et al., 1994; ${ }^{2}$ Bowen and Washburn, 1985; ${ }^{3}$ Altıntaş and Fidanc1, 1993; ${ }^{4}$ Polonovski, 1971

Means for serum constituents and haematocrit values are presented in Table 4. The percentage of haematocrit was higher in the feed withdrawal and 
darkening groups compared with the control $(\mathrm{P}<0.01)$. Feed withdrawal and darkening treatments increased serum glucose $(\mathrm{P}<0.01)$, total protein $(\mathrm{P}<0.01)$, urea-N $(\mathrm{P}<0.05)$, uric acid $(\mathrm{P}<0.01)$, albumin $(\mathrm{P}<0.05)$, triglyceride $(\mathrm{P}<0.01)$, cholesterol $(\mathrm{P}<0.05), \mathrm{Ca}(\mathrm{P}<0.01), \mathrm{P}(\mathrm{P}<0.01), \mathrm{Na}(\mathrm{P}<0.05)$, and $\mathrm{K}(\mathrm{P}<0.05)$ concentrations, and also the activities of amylase $(\mathrm{P}<0.05)$ and alkaline phosphatase $(\mathrm{P}<0.05)$. No differences were found $(\mathrm{P}>0.05)$ for activities of SGPT and SGOT, and serum creatinine concentration among treatments.

Table 4

The effects of feed withdrawal and darkening on some serum metabolites, enzyme activities, and mineral concentrations of laying hens reared under heat stress $(n=10)$

\begin{tabular}{lcccc}
\hline \multicolumn{1}{c}{ Item } & Control & Feed withdrawal & Darkening & Reference values \\
\hline Haematocrit, \% & $33.1 \pm 0.2^{\mathrm{a}}$ & $35.8 \pm 0.5^{\mathrm{b}}$ & $37.6 \pm 0.3^{\mathrm{c}}$ & $25-37^{1}$ \\
Glucose, mmol/1 & $10 \pm 0.16^{\mathrm{a}}$ & $11 \pm 0.17^{\mathrm{b}}$ & $11.3 \pm 0.10^{\mathrm{c}}$ & $10-12^{2,3,4}$ \\
Total protein, g/l & $43 \pm 0.7^{\mathrm{a}}$ & $44 \pm 0.5^{\mathrm{b}}$ & $45 \pm 0.3^{\mathrm{c}}$ & $25-45^{5}$ \\
Urea-N, mmol/1 & $0.23 \pm 0.01^{\mathrm{a}}$ & $0.25 \pm 0.03^{\mathrm{b}}$ & $0.30 \pm 0.04^{\mathrm{c}}$ & $0.20-0.30^{2,3}$ \\
Uric acid, mmol/1 & $0.24 \pm 0.02^{\mathrm{a}}$ & $0.26 \pm 0.03^{\mathrm{b}}$ & $0.28 \pm 0.02^{\mathrm{c}}$ & $0.22-0.30^{2,3,5}$ \\
Albumin, g/l & $14.9 \pm 0.3^{\mathrm{a}}$ & $15.7 \pm 0.2^{\mathrm{b}}$ & $16.1 \pm 0.3^{\mathrm{c}}$ & $15-35^{4,6}$ \\
Triglyceride, mmol/1 & $3.79 \pm 0.03^{\mathrm{a}}$ & $4.09 \pm 0.04^{\mathrm{b}}$ & $4.67 \pm 0.04^{\mathrm{c}}$ & $<2.73^{4,5,6}$ \\
Cholesterol, mmol/1 & $8.63 \pm 0.12^{\mathrm{a}}$ & $8.86 \pm 0.07^{\mathrm{b}}$ & $9.17 \pm 0.08^{\mathrm{c}}$ & $5.86-11.5^{2,3,4}$ \\
Creatinine, mmol/1 & $0.036 \pm 0.002$ & $0.044 \pm 0.001$ & $0.044 \pm 0.002$ & $0.03-0.05^{4,6}$ \\
SGOT, U/L & $171.8 \pm 3.3$ & $169.0 \pm 1.8$ & $160.2 \pm 5.2$ & $30-180^{2,3,4}$ \\
SGPT, U/L & $16.4 \pm 0.8$ & $16.6 \pm 0.5$ & $15.8 \pm 0.6$ & $4-20^{2,3,4}$ \\
Amylase, U/L & $340.4 \pm 3.5^{\mathrm{a}}$ & $369.0 \pm 2.9^{\mathrm{b}}$ & $389.5 \pm 1.8^{\mathrm{c}}$ & $296-638^{2,3,4}$ \\
A. phosphatase, U/L & $253.1 \pm 2.0^{\mathrm{a}}$ & $264.0 \pm 1.8^{\mathrm{b}}$ & $283.3 \pm 2.5^{\mathrm{c}}$ & $200-1060^{2,3,4}$ \\
Ca, mmol/l & $4 \pm 0.7^{\mathrm{a}}$ & $4.25 \pm 0.3^{\mathrm{b}}$ & $4.55 \pm 0.2^{\mathrm{c}}$ & $3.75-7.20^{2,3,4,6}$ \\
$\mathrm{P}, \mathrm{mmol} / \mathrm{l}$ & $1.96 \pm 0.02^{\mathrm{a}}$ & $2.07 \pm 0.02^{\mathrm{b}}$ & $2.10 \pm 0.01^{\mathrm{c}}$ & $1.61-1.98^{4,6}$ \\
$\mathrm{Na}, \mathrm{mmol} / \mathrm{l}$ & $153 \pm 0.9^{\mathrm{a}}$ & $155 \pm 1.2^{\mathrm{b}}$ & $157 \pm 1.0^{\mathrm{c}}$ & $152-153^{2,3,4,6}$ \\
$\mathrm{~K}, \mathrm{mmol} / \mathrm{l}$ & $0.48 \pm 0.03^{\mathrm{a}}$ & $0.64 \pm 0.05^{\mathrm{b}}$ & $0.74 \pm 0.04^{\mathrm{c}}$ & $0.32-0.95^{2,3,4,6}$ \\
\hline
\end{tabular}

a,b,c Means in the same row with different superscripts differ significantly $(\mathrm{P}<0.05)$; ${ }^{1}$ Yahav et al., 1997; ${ }^{2}$ Polonovski, 1971; ${ }^{3}$ Svenson, $1970 ;{ }^{4}$ Altıntas and Fidanc1, 1993; Kaneko, 1989; ${ }^{6}$ Belay and Teeter, 1996

\section{Discussion}

Results of the present study showed that the control group (heat-stressed) had greater depression of feed intake, liveweight change, and egg production compared with the feed withdrawal and darkening groups (less heat-stressed) during the hot days of summer months. In other words, feed withdrawal and darkening treatments, particularly darkening, reduced the negative effects of heat stress on performance. Increased water intake in the control group also was evidence of a greater heat stress compared with the other treatments. Increased water intake helps increase respiration efficiency in birds (Belay and Teeter, 1993). Since water also serves as a heat receptor it relieves the heat stress as well (Belay 
and Teeter, 1993). The relationship between performance and heat stress in the present study is in agreement with those reported by others (McCormick et al., 1979; Marsden et al., 1987). It has been well known that growth rate, feed intake, and egg production decrease when ambient temperature increases above thermoneutral zone which ranges from 16 to $25^{\circ} \mathrm{C}$ (Quart et al., 1989; Musharaf and Jansen, 1990). Feed intake has a thermogenic effect due to its heat increment upon digestion, adding more heat to an already heat-stressed system (Meltzer et al., 1983). In this case, the bird may protect itself from an aggravated heat stress by lowering its voluntary feed intake. In the present study, feed withdrawal and darkening treatments increased liveweight by 1.58 and $3.74 \%$, and egg production by 11.26 and $24.38 \%$, respectively. Increases in these responses occurred via increased feed intake by 5.35 and $10.71 \%$, for feed withdrawal and darkening groups, respectively. Every 1\% increase in feed intake resulted in 2.4 and $2.3 \%$ increases in egg production for the darkening and the feed withdrawal groups, respectively. Although the magnitude of egg production per unit of feed intake was similar between feed withdrawal and darkening groups, darkening resulted in a higher egg production percentage (69 vs. $62 \%$ ) which is more important from the perspective of producers. In the present study, the depression of feed intake in the control group was reflected as a reduction in egg production; also, increased egg production in feed withdrawal and darkening was probably due to increased feed intake.

To avoid more stress blood samples were collected only once. In the present study, feed withdrawal and darkening increased T3, T4, and TSH concentrations. In other words, the heat-stressed group (control) had lower concentrations of T3, T4, and TSH. Similarly, several researchers reported reduced plasma concentrations of T3 and T4 in heat-stressed chickens (Heninger et al., 1960; Johnson, 1981; Bowen et al., 1984; Rudas and Pethes, 1984). It has been suggested that thyroid activity is affected by environmental temperature (McNabb and King, 1993; Yahav et al., 1997). Huston and Carmon (1962) reported that thyroid size and thyroid secretion rate decreased at high temperatures and increased at low temperatures.

Feed withdrawal and darkening caused a decreased ACTH plasma concentration, indicating a lowered response to heat stress. The higher ACTH plasma concentration of the control group, compared with other treatments, was probably due to the greater effects of heat stress on the control group.

Most of the plasma enzymes, metabolites, and mineral concentrations were influenced by feed withdrawal and darkening treatments. Increases in most blood parameters were greater with darkening compared with feed withdrawal group. Heat-stressed hens (control) had lower concentrations of glucose, total protein, urea-N, albumin, triglycerides, and cholesterol compared with hens less heat-stressed (feed withdrawal and darkening groups). Similarly, Deyhim et al. (1995) reported decreased concentrations of total protein, albumin, triglycerides, and uric acid in heat-distressed broiler chickens. However, serum glucose con- 
centrations were reported to increase (Deyhim et al., 1995) or remain unchanged (Koelkebeck and Odom, 1995) in heat-stressed laying hens and broiler chickens. Corticosteroids have been known to increase plasma glucose concentration of several bird species (Riddle, 1937; Stamler et al., 1954; Snedecor et al., 1963). However, Siegel et al. (1984) found no increases in plasma glucose of Japanese quails receiving chronic injections of ACTH. In the present study, although ACTH concentration was higher, serum glucose, total protein, and triglycerides were lower in the control (heat-stressed) group compared with other treatments. These controversial results (Riddle, 1937; Stamler et al., 1954; Snedecor et al., 1963; Siegel et al., 1984; Koelkebeck and Odom, 1995; the present study) should be related to the duration of stress. Plasma corticosteroid concentration has been shown to increase rapidly as a result of heat exposure $\left(45^{\circ} \mathrm{C}\right)$, peak after one hour, and finally decrease as the heat exposure continued (Siegel, 1995). This response of corticosteroids indicates the failure of maintenance of synthesis or release of corticosteroids (Siegel, 1995).

Plasma activities of SGOT, SGPT and alkaline phosphatase were lower in heat-stressed hens (control) compared with hens receiving feed withdrawal and darkening treatments. Plasma concentrations of $\mathrm{Ca}, \mathrm{P}, \mathrm{Na}$, and $\mathrm{K}$ were also lower in the control group compared with other treatments. In agreement with our results, high temperature has been found to decrease blood plasma $\mathrm{Ca}, \mathrm{Na}$, and $\mathrm{P}$ concentrations in broilers (Donoghue et al., 1990; Belay and Teeter, 1993) and turkeys (Kohne and Jones, 1975). However, Koelkebeck and Odom (1995) reported no changes in serum concentrations of inorganic phosphate, calcium, potassium, and sodium of heat-stressed laying hens. Concentrations of most serum parameters measured in the present study were higher in the experimental groups compared to the control group. Lower water consumption was probably the reason for relatively high serum data in the experimental groups. Greater haematocrit values of the experimental groups also support this possibility.

In terms of reducing the cost of production, the present study proves that the practice of both feed withdrawal and darkening can be inexpensive ways in reducing the negative effects of heat stress for poultry inevitably exposed to heat stress during rearing conditions in many parts of the world including Turkey, particularly during the summer months.

The results of the present study concluded that both darkening and feed withdrawal, particularly darkening, may offer a potential protective management practice in preventing heat stress-induced feed intake and egg production depression in laying hens.

\section{Acknowledgements}

The authors thank the Veterinary Control and Research Institute of the Ministry of Agriculture, Elazı , for providing the research facility. The study was funded by Firat University Funds, Technical Committee FÜNAF- 263. 


\section{References}

A.O.A.C. (1990): Official Methods of Analysis. Association of Agricultural Chemists. Virginia, D. C., U.S.A.

Altıntas, A. and Fidanc1, U. R. (1993): Revue bibliographique sur les valeurs normales biochimiques pour certains parametres sanguins chez les animaux domestiques et chez l'homme. A. Ü. Vet. Fak. Derg. 40, 173-186.

Belay, T. and Teeter, R. G. (1993): Broiler water balance and thermobalance during thermoneutral and high ambient temperature exposure. Poultry Sci. 72, 116-124.

Belay, T. and Teeter, R. G. (1996): Virginiamycin and caloric density effects on live performance, blood serum metabolite concentration, and carcass composition of broilers reared in thermoneutral and cycling ambient temperatures. Poultry Sci. 75, 1383-1392.

Bowen, S. J. and Washburn, K. W. (1985): Thyroid and adrenal response to heat stress in chickens and quail differing in heat tolerance. Poultry Sci. 64, 149-154.

Bowen, S. J., Washburn, K. W. and Huston, T. M. (1984): Involvement of the thyroid gland in the response of the young chicken to heat stress. Poultry Sci. 63, 66-69.

Chiericato, G. M., Licia, R. and Chiara, R. (1994): Study of the metabolic profile of rabbits in relation to two different environmental temperatures. World Rabbit Sci. 2, 153-160.

Crampton, E. W. and Maynard, L. (1938): The relation of cellulose and lignin content to nutritive value of animal feeds. J. Nutr. 15, 383-395.

Deyhim, F., Stoecker, B. S., Adeleye, B. G. and Teeter, R. G. (1995): The effect of heat distress environment, vitamin, and trace mineral supplementation on performance, blood constituents, and tissue mineral concentrations in broiler chickens. Nutr. Research 15, 521-526.

Donoghue, D. J., Krueger, W. F., Donoghue, A. M., Byrd, J. A., Ali, D. H. and El Halavani, M. H. (1990): Magnesium aspartate-hydrochloride reduces weight loss in heat-stressed laying hens. Poultry Sci. 69, 1862-1868.

Edens, F. W. and Siegel, H. S. (1975): Adrenal responses in high and low ACTH response lines of chickens during acute heat stress. Gen. Comp. Endocrinol. 25, 64-73.

Emery, D. A., Vohra, P., Ernst, R. A. and Morrison, S. R. (1984): The effect of cyclic and constant ambient temperatures on feed consumption, egg production, egg weight and shell thickness of hens. Poultry Sci. 63, 2027-2035.

Evans, S. E. and Ingram, D. L. (1977): The effect of ambient temperature upon the secretion of thyroxine in the young pig. J. Physiol. 264, 511-518.

Feenster, R. (1985): High temperatures decrease vitamin utilization. Poultry, December 1985, pp. 38-41.

Heninger, R. W., Newcomer, W. S. and Thayer, R. H. (1960): The effect of elevated ambient temperatures and the thyroxine secretion rate of chickens. Poultry Sci. 39, 1332-1337.

Hilmann, P. E., Scott, N. R. and Van Tienhoven, A. (1985): Physiological responses and adaptations to hot and cold environments. In: Yousef, M. K. (ed.) Stress Physiology in Livestock. CRC Press Inc., Boca Raton, Florida. pp. 1-71.

Huston, T. M. and Carmon, J. L. (1962): The influence of high environmental temperature on thyroid size of domestic fowl. Poultry Sci. 41, 175-183.

Johnson, H. D. (1981): Limiting stress of food producing animals to increase efficiency. Rep. Ann. Coop. Western Region Res. Project W-135 Mtg.

Kaneko, J. J. (1989): Clinical Biochemistry of Domestic Animals. Academic Press, Inc., San Diego.

Klandorf, H. and Harvey, S. (1985): Food intake regulation of circulating thyroid hormones in domestic fowl. Gen. Comp. Endocrinol. 62, 162-170.

Koelkebeck, K. W. and Odom, T. W. (1995): Laying hen responses to acute heat stress and carbon dioxide supplementation: II. Changes in plasma enzymes, metabolites and electrolytes. Comp. Biochem. Physiol. 112, 119-122. 
Kohne, H. J. and Jones, J. E. (1975): Changes in plasma electrolytes, acid-base balance and other physiological parameters of adult female turkeys under conditions Acute Hyperthermia. Poultry Sci. 51, 2034-2038.

Kutlu, H. R. and Forbes, J. M. (1995): Alleviation of the effect of heat stress by dietary methods in broilers. W. Rev. Anim. Prod. 50, 294-300.

Marsden, A., Morris, T. R. and Cromatry, A. S. (1987): Effects of constant environmental temperatures on the performance of laying pullets. British Poult. Sci. 28, 361-380.

McNabb, F. M. A. and King, D. B. (1993): Thyroid hormones: effect on growth, development and metabolism. In: Schreibman, M. P., Scanes, C. G. and Pang, P. K. T. (eds) The Endocrinology of Growth, Development and Metabolism in vertebrates. Zoological Sci. 10, 873885.

McCormick, C. C., Garlich, J. D. and Edens, F. W. (1979): Fasting and diet affect the tolerance of young chickens exposed to acute heat stress. J. Nutr. 109, 1797-1809.

McKee, J. S., Harrison, P. C. and Ariskowski, G. L. (1997): Effect of supplemental ascorbic acid on the energy conversion of broiler chicks during heat stress and feed withdrawal. Poultry Sci. 76, 1278-1286.

Meltzer, M. A., Macleod, M. G. and White, J. (1983): Air movement, locomotor activity and heat loss in small animals. ARC Poultry Research Center. Annual Report, 85 pp.

Meluzzi, A., Primiceri, G., Giordani, R. and Fabris, G. (1992): Determination of blood constituents reference values in broilers. Poultry Sci. 71, 337-345.

Musharaf, N. A. and Jansen, V. M. (1990): The effect of water temperature and feed density on the performance of laying hens during heat stress. Sudan J. Anim. Nutr. 3, 17-26.

National Research Council (1994): Nutrient Requirements of Poultry. 9th rev. edition. National Academy Press, Washington, DC.

Polonovski, M. (1971): Elements de biochimie medicale. In: Boulanger, P., Polonovski, J., Tayean, F., Mandel, P. and Biserte, G. (eds) Biochimie medicale. 8th edition. Masson et cie Eduiteurs, Paris.

Quart, M. D., Damron, B. L. and Mather, F. B. (1989): Effects of short-term fasting and diurnal heat stress on broiler performance and behavior. Poultry Sci. 68, 55-60.

Renden, J. A., Lien, R. J. Oates, S. S. and Bilgili, S. (1994): Plasma concentrations of corticosterone and thyroid hormones in broilers provided various lighting schedules. Poultry Sci. 73, $186-193$.

Riddle, O. (1937): On carbohydrate metabolism in pigeons. Cold Spring Harbor Symposium on Quantitative Biology 5, 362-374.

Rudas, P. and Pethes, G. (1984): Studies on the conversion of thyroxine to 3,5,3'-triiodothyronine in normal and thyroidectomized chickens. Gen. Comp. Endocrinol. 54, 154-161.

Sas Institute (1985): SAS ${ }^{\circledR}$ User's Guide: Statistics. SAS Institute Inc., Cary, NC.

Sauveur, B. and Picard, M. (1987): Environmental effects on egg quality. In: Wells, R. G. and Belyavin, C. G. (eds) Egg Quality - Current Problems and Recent Advances. Butterworths, London, UK. pp. 219-234.

Siegel, H. S. (1995): Stress, strains and resistance. British Poultry Sci. 36, 3-22.

Siegel, H. S., Marks, H. L. and Latimer, J. W. (1984): Agglutinin responses to Salmonella pullorum in Japanese quail selected for plasma cholesterol responses to ACTH and a model describing the dynamics of the response. Poultry Sci. 63, 1892-1894.

Snedecor, J. G., King, D. B. and Hendrikson, R. C. (1963): Studies on chick glycogen body: effects of hormones and normal glycogen turnover. Gen. Comp. Endocrinol. 3, 176-183.

Stamler, J., Pick, R. and Katz, L. N. (1954): Effect of cortisone, hydrocortisone, and corticosterone on lipemia, glycemia and atherogenesis in cholesterol fed chicks. Circulation 10, 237-246.

Svenson, J. M. (1970): Duke's Physiology of Domestic Animals. 7th edition, Cornell University Press, London.

Yahav, S., Straschnow, A., Plavnik, I. and Hurwitz, S. (1997): Blood system response of chickens to changes in environmental temperature. Poultry Sci. 76, 627-633. 